University of Nebraska - Lincoln

DigitalCommons@University of Nebraska - Lincoln

10-2005

\title{
Mountain Plover Population Responses to Black-Tailed Prairie Dogs in Montana
}

\author{
Stephen J. Dinsmore \\ Colorado State University, cootjr@iastate.edu
}

Gary C. White

Colorado State University - Fort Collins, Gary.White@ColoState.edu

Fritz L. Knopf

U.S. Geological Survey

Follow this and additional works at: https://digitalcommons.unl.edu/usgsstaffpub

Part of the Earth Sciences Commons

Dinsmore, Stephen J.; White, Gary C.; and Knopf, Fritz L., "Mountain Plover Population Responses to Black-Tailed Prairie Dogs in Montana" (2005). USGS Staff -- Published Research. 48.

https://digitalcommons.unl.edu/usgsstaffpub/48

This Article is brought to you for free and open access by the US Geological Survey at DigitalCommons@University of Nebraska - Lincoln. It has been accepted for inclusion in USGS Staff -- Published Research by an authorized administrator of DigitalCommons@University of Nebraska - Lincoln. 


\section{allen press}

Mountain Plover Population Responses to Black-Tailed Prairie Dogs in Montana

Author(s): Stephen J. Dinsmore, Gary C. White, Fritz L. Knopf

Source: The Journal of Wildlife Management, Vol. 69, No. 4 (Oct., 2005), pp. 1546-1553

Published by: Allen Press

Stable URL: http://www.jstor.org/stable/3803514

Accessed: 23/06/2009 00:45

Your use of the JSTOR archive indicates your acceptance of JSTOR's Terms and Conditions of Use, available at http://www.jstor.org/page/info/about/policies/terms.jsp. JSTOR's Terms and Conditions of Use provides, in part, that unless you have obtained prior permission, you may not download an entire issue of a journal or multiple copies of articles, and you may use content in the JSTOR archive only for your personal, non-commercial use.

Please contact the publisher regarding any further use of this work. Publisher contact information may be obtained at http://www.jstor.org/action/showPublisher?publisherCode=acg.

Each copy of any part of a JSTOR transmission must contain the same copyright notice that appears on the screen or printed page of such transmission.

JSTOR is a not-for-profit organization founded in 1995 to build trusted digital archives for scholarship. We work with the scholarly community to preserve their work and the materials they rely upon, and to build a common research platform that promotes the discovery and use of these resources. For more information about JSTOR, please contact support@ jstor.org. 


\title{
MOUNTAIN PLOVER POPULATION RESPONSES TO BLACK-TAILED PRAIRIE DOGS IN MONTANA
}

STEPHEN J. DINSMORE, 1,2 Department of Fishery and Wildife Biology, Colorado State University, Fort Collins, CO 80523 USA GARY C. WHITE, Department of Fishery and Wildlife Biology, Colorado State University, Fort Collins, CO 80523 USA

FRITZ L. KNOPF, U.S. Geological Survey, Biological Resources Division, Fort Collins Science Center, 2150-C Centre Avenue, Fort Collins, CO 80525 USA

\begin{abstract}
We studied a local population of mountain plovers (Charadrius montanus) in southern Phillips County, Montana, USA, from 1995 to 2000 to estimate annual rates of recruitment rate $(f)$ and population change $(\lambda)$. We used Pradel models, and we modeled $\lambda$ as a constant across years, as a linear time trend, as year-specific, and with an additive effect of area occupied by prairie dogs (Cynomys ludovicianus). We modeled recruitment rate $(f)$ as a function of area occupied by prairie dogs with the remaining model structure identical to the best model used to estimate $\lambda$. Our results indicated a strong negative effect of area occupied by prairie dogs on both $\lambda$ (slope coefficient on a log scale was $-0.11 ; 95 \% \mathrm{CI}$ was $-0.17,-0.05)$ and $f$ (slope coefficient on a logit scale was $-0.23 ; 95 \% \mathrm{CI}$ was $-0.36,-0.10$ ). We also found good evidence for a negative time trend on $\lambda$; this model had substantial weight $\left(w_{i}=0.31\right)$, and the slope coefficient on the linear trend on a $\log$ scale was $-0.10(95 \% \mathrm{CI}$ was $-0.15,-0.05)$. Yearly estimates of $\lambda$ were $>1$ in all years except 1999, indicating that the population initially increased and then stabilized in the last year of the study. We found weak evidence for year-specific estimates of $\lambda$; the best model with year-specific estimates had a low weight $\left(w_{i}=0.02\right)$, although the pattern of yearly estimates of $\lambda$ closely matched those estimated with a linear time trend. In southern Phillips County, the population trend of mountain plovers closely matched the trend in the area occupied by black-tailed prairie dogs. Black-tailed prairie dogs declined sharply in the mid-1990s in response to an outbreak of sylvatic plague, but their numbers have steadily increased since 1996 in concert with increases in plovers. The results of this study (1) increase our understanding of the dynamics of this population and how they relate to the area occupied by prairie dogs, and (2) will be useful for planning plover conservation in a prairie dog ecosystem.
\end{abstract}

JOURNAL OF WILDIFE MANAGEMENT 69(4):1546-1553; 2005

Key words: Charadrius montanus, Cynomys ludovicianus, Montana, mountain plover, population trend, prairie dog, status.

The finite rate of population change, lambda $(\lambda)$, is often of fundamental importance to ecologists interested in assessing population status. Estimates of lambda can show that a population is increasing $(\lambda>1)$, stable $(\lambda=1)$, or declining $(\lambda<1)$ and provide a more formal means of interpreting estimates of population size. Understanding these rates becomes even more important for rare or declining species that require immediate intervention to rescue them from further declines or extinction.

The traditional method of estimating $\lambda$ has been with the use of Leslie projection matrices (Leslie 1945, Caswell 2001). Under this method, measures of average age-specific survival and fecundity are used to project population growth over a specified period. However, this method has problems. The most important flaw is that the rates that are often used represent averages over a specified time period, so predicted values of $\lambda$ are also averages and may not be reasonable pre-

\footnotetext{
${ }^{1}$ Present address: Department of Natural Resource Ecology and Management, Iowa State University, 339 Science II, Ames, IA 50011.

2 E-mail: cootjr@iastate.edu
}

dictors of future trends. Additionally, estimates of $\lambda$ from projection matrices may be biased downward if there is substantial emigration, particularly among juvenile age classes (Franklin et al. 1996).

Pradel (1996) introduced a reparameterization of the Jolly-Seber model to estimate the finite rate of population change $(\lambda)$ in addition to apparent survival $(\phi)$ and conditional capture probability $(p)$. Unlike the Leslie projection matrix, this method dìrectly accounts for internal (reproduction and mortality) and external (immigration and emigration) influences on the population of interest and is an improvement because $\lambda$ is estimated directly from the data.

Mountain plovers are a local and declining shorebird of the western Great Plains (Knopf 1994). Perceived declines led to a proposal to list them as a Threatened species in 1999 (U.S. Department of the Interior 2002). Rigorous assessment of plover status and trends at key breeding areas is needed and will provide a better understanding of local population dynamics and help future conservation efforts for this species.

We provide estimates of annual rates of population change $(\lambda)$ from 1995 to 1999 for a population of mountain plovers in southern Phillips 
County, Montana. Southern Phillips County is thought to contain the largest breeding population of plovers in Montana and one of the largest in North America (Knopf and Miller 1994). We discuss population trends at this site in light of the total size of this population (Dinsmore et al. 2003) and changes in the area occupied by blacktailed prairie dogs. We then comment on the status and future outlook for mountain plovers at this key breeding site, and we identify several aspects of their biology needing further study.

\section{STUDY AREA}

We studied mountain plovers on a $3,000-\mathrm{km}^{2}$ area in southern Phillips County in north-central Montana $\left(47^{\circ} 40^{\prime}-47^{\circ} 55^{\prime} \mathrm{N}, 107^{\circ} 35^{\prime}-108^{\circ} 30^{\prime} \mathrm{W}\right.$; Fig. 1). The study area was bounded by the Missouri River to the south, the Sun Prairie and Content roads to the east, Beaver Creek to the north, and Highway 191 to the west. Approximately $2,250 \mathrm{~km}^{2}$ of the study area was in public ownership with the Bureau of Land Management (BLM, Malta Field Office) and the U.S. Fish and Wildlife Service (USFWS, Charles M. Russell National Wildlife Refuge). This area was a mixed-grass prairie with sagebrush flats bordering the southwestern edge of the Prairie Pothole Region (Knowles et al. 1982, Olson and Edge 1985). Predominant vegetation included big sagebrush (Artemisia tridentata), silver sagebrush (Artemisia cana), greasewood (Sarcobatus vermiculatus), yellow sweetclover (Melilotus officinalis), green needlegrass (Stipa viridula), and western wheatgrass (Agropyron smithii). Active black-tailed prairie dog colonies contained variable amounts of bare ground interspersed with sparse vegetation that included fringed sagewort (Artemisia frigida), plains prickly pear (Opuntia polycantha), blue grama (Bouteloua gracilis), needle-and-thread grass (Stipa comata), and Sandberg bluegrass (Poa secunda), with fewer grasses generally present on the older colonies. Mean annual precipitation near the center of the study area was $33 \mathrm{~cm}$, most of which fell from May to July (D. Veseth, Veseth and Veseth Inc., personal communication). Mean elevation was approximately $930 \mathrm{~m}$.

We studied mountain plovers exclusively on or adjacent to active black-tailed prairie-dog colonies because previous research found that mountain plovers preferentially used such sites in Montana (Knowles et al. 1982, Knowles and Knowles 1984). Prairie-dog numbers fluctuated considerably in southern Phillips County, mainly as a result of outbreaks of sylvatic plague, an epizootic (Barnes 1993), although recreational shooting may have a

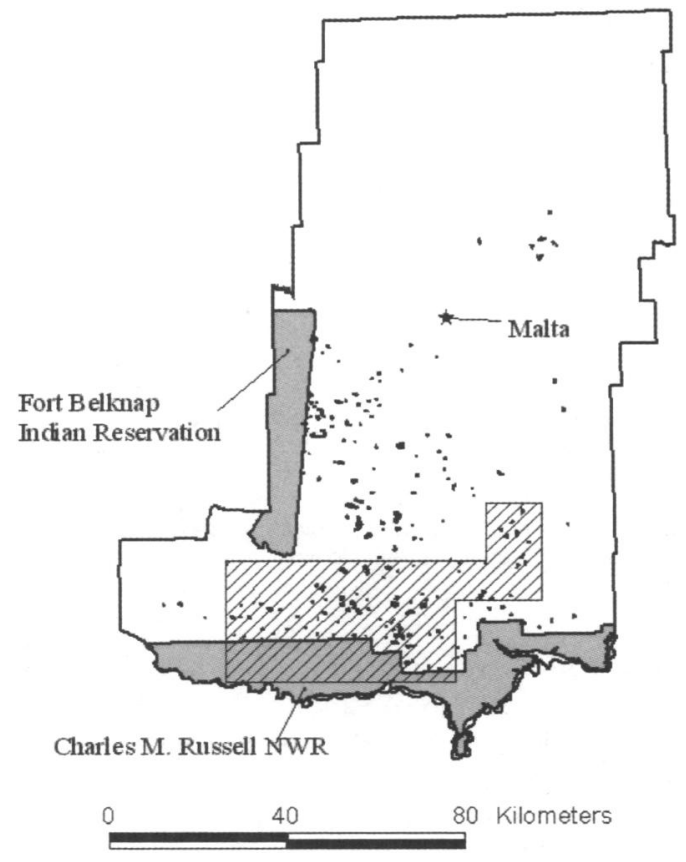

Fig. 1. Map of Phillips County, Montana, USA, showing the distribution in 2000 of black-tailed prairie-dog colonies. The stippled region represents the study area.

negative impact on some of the smaller prairie-dog colonies (Vosburgh and Irby 1998). Prairie dogs have rapidly recovered from the last major plague outbreak in 1992-96. Colony areas were reduced by about $80 \%$ during this outbreak, but they have since increased from 1,371 ha in 1995 to 5,071 ha in 2000 (J. Grensten, Bureau of Land Management, personal communication; Fig. 2). Inactive colonies, mostly the result of plague outbreaks, were not included in this total because habitat on such colonies rapidly became unsuitable for plovers, often within a matter of a few weeks.

\section{METHODS}

\section{Capture and Marking}

We studied mountain plovers from 20 May to 20 July during 6 breeding seasons (1995-2000). We systematically searched active prairie-dog colonies within the study area $\geq 3$ times each year. On these searches we slowly drove a vehicle across each colony and periodically stopped to scan for plovers. We watched individual adult birds from a distance until they returned to a nest. Once we located a nest, we trapped the adult immediately with a walk-in, wire-mesh trap placed over the nest, and we then banded the bird with a unique 


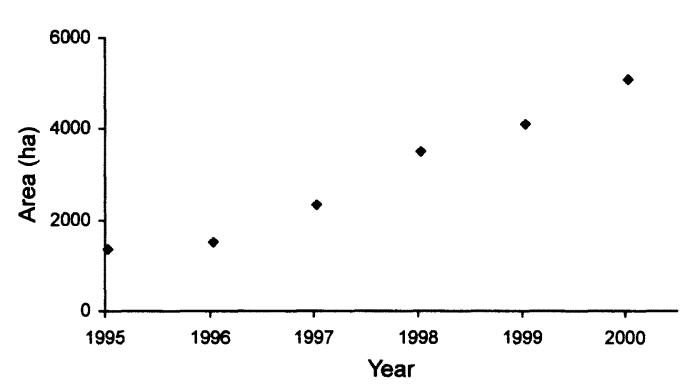

Fig. 2. Area occupied by black-tailed prairie dogs in southern Phillips County, Montana, USA, 1995-2000. We calculated areas from annual Bureau of Land Management surveys; areas from 1998 and 2000 were from complete censuses, while all other estimates were predicted areas based on annual counts of $1 / 3$ of all known colonies.

combination of 4 colored leg bands and an aluminum, size 3A USFWS numbered leg band. We derived color-band combinations from 6 possible colors (red, orange, yellow, dark blue, green, white) that we chose to minimize possible reading errors. We used ultraviolet (UV) stable Darvac leg bands (A. C. Hughes, London) to reduce color fading. We released all plovers within 15 minutes of capture. We typically banded juvenile plovers as flightless chicks (>10 days old). In July, we occasionally trapped and banded small numbers $(<10$ per year) of juvenile and adult plovers at night. We located the birds at roosts with a spotlight, approached them on foot, and captured them in a large dip-net. Capture techniques did not result in any immediate mortalities. The Colorado State University Animal Care and Use Committee approved the field methods (Protocol 98-134A-01).

\section{Surveys for Marked Plovers}

We searched all known, active prairie-dog colonies within the study area $\geq 3$ times each year. Searches were divided among 3 secondary sampling periods (20 May-10 Jun, 11-30 Jun, 1-20 Jul), with a minimum of 1 search per sampling period. We conducted live recaptures by resighting marked plovers. For all plovers, we recorded the age (adult or juvenile) and exact sequence of color bands, if the bird was marked. We trained all individuals involved in resighting plovers prior to fieldwork to minimize possible errors reading color band combinations (Milligan et al. 2003). We believe that reading error rates were low because plovers were approachable, were typically detected singly, and were marked with leg bands of contrasting colors.

\section{Estimating Population Trends $(\lambda)$}

We estimated the finite rate of population change $(\lambda)$ and recruitment $(f)$ using the Pradel lambda models (Pradel 1996) in program MARK (White and Burnham 1999). We estimated annual apparent survival and population size earlier using the robust design (Dinsmore et al. 2003); our focus was only on estimates of $\lambda$ and $f$. Models to estimate $\lambda$ directly from a robust design study have not been developed, so we were forced to slightly modify our approach to estimating $\lambda$ and $f$ with this model.

We summarized releases and live resightings of banded plovers in encounter history format with 6 encounter occasions, 1 for each year of the study. We only used information from adult plovers, which included all birds first banded as adults and all juveniles that were subsequently resighted as adults. Using this approach, we estimated the annual rate of the breeding adult population change $(\lambda)$ for 5 years (1995-1999) and recruitment $(f)$ for 5 years (1996-2000).

Our general approach to modeling $\lambda$ and $f$ followed Lebreton et al. (1992) and Burnham and Anderson (2002). We first developed a list of a priori factors influencing each parameter $(\phi, p, f$, $\lambda$ ), and we then used this information to define a set of candidate models.

The Pradel models allowed the simultaneous estimation of apparent survival $(\phi)$ with capture probability $(p)$ and the finite rate of population change $(\lambda)$ or recruitment $(f)$. Because there was only a single encounter occasion per year, we could not estimate the recapture probability $(c)$. Under this model, population change was estimated as:

$$
\hat{\lambda}_{t}=\frac{N_{t+1}}{N_{t}}
$$

where $N_{t}$ represented the population size at some time $t$. Between times $t$ and $t+1$ the population changed as a function of births, deaths, emigration, and immigration. Thus, changes in $\lambda$ were a function of apparent survival, recruitment, and movement.

To estimate $\lambda$ using the Pradel model, we had to model annual apparent survival and initial capture probability correctly. For mountain plovers, we modeled apparent survival $(\phi)$ as year-specific. Because we believed $\lambda$ changed annually, it made sense to also allow survival to vary annually, even though we suspected yearly differences in adult survival were small (Dins- 
more et al. 2003). For comparison, we also included a single model where apparent survival was constant across years.

The initial capture of mountain plovers occurred by either physical capture $(p)$ or resighting $(r)$, and we knew from earlier work that the probability of physical capture was much lower than resighting probability (Dinsmore et al. 2003). In an earlier analysis, we showed that models where $p=r+\mathrm{C}$, where $\mathrm{C}$ was some constant, received the best support (Dinsmore et al. 2003). Limitations in the structure of the Pradel model prohibited modeling $p$ and $r$ separately, so we were forced to model all initial captures with probability $p$. We considered 2 constraints on capture probability: We let it be constant across years $\left[p_{(.)}\right]$and allowed it to vary by year $\left[p_{(t)}\right]$. Because differences in yearly capture probabilities using the robust design were small (Dinsmore et al. 2003), we hypothesized that models with constant capture probability would receive better support than those with time-specific capture probability, but this was somewhat speculative. Therefore, we considered the use of both of these constraints on capture probability partly exploratory.

For lambda $(\lambda)$, we considered 4 constraints. We considered 2 models with full time variation where $\lambda$ varied by year $\left[\lambda_{(t)}\right] ; \phi$ was also year-specific in both models, while $p$ was constant in 1 model and year-specific in the other. We also considered a model where $\lambda$ had a linear time trend $\left[\lambda_{(T)}\right] ; \phi$ was year-specific, and $p$ was constant. We next considered a model where $\lambda$ was constant $\left[\lambda_{(.)}\right]$, but only when $\phi$ and $p$ were also constant; a model with constant $\lambda$ and time variation on $\phi$ and $p$ was nonsensical. Finally, we considered a model where $\lambda$ was a function of the hectares of active prairiedog colonies $\left[\lambda_{\text {prairie dog }}\right]$. This latter model was an attempt to solidify the relationship between these 2 species that we found earlier (Dinsmore et al. 2003). Thus, temporal variation in $\lambda$ was accounted for by recruitment and immigration in the first case and by recruitment, immigration, and apparent survival in the second case. We modeled lambda models on a log scale, where:

$$
\log (\lambda)=\hat{\beta}_{0}+\hat{\beta}_{1}(X)
$$

and $X$ represented some variable of interest such as the area occupied by prairie dogs or a linear time trend.

In an attempt to better understand possible causes of annual population trends, we also considered a single model where recruitment $(f)$ was estimat- ed instead of population trend $(\lambda)$. In this model, recruitment was a function of the hectares of active prairie-dog colonies and used the same constraints on $\phi$ and $p$ that were in the best survival and $\lambda$ model. Here, $f$ was defined as the number of new animals in the population at time $i$, per animal that was in the population at time $i-1$ (Franklin 2000). The relationship between lambda, apparent survival, and recruitment was simply $\lambda=\phi+f$. Therefore, $f$ estimated the portion of apparent survival that was due to recruitment. We modeled recruitment models on the logit scale, where:

$$
\operatorname{logit}(f)=\ln \left(\frac{f}{f-1}\right) \hat{\beta}_{0}+\hat{\beta}_{1}(X),
$$

and $X$ represented some variable of interest such as the area occupied by prairie dogs.

With these guidelines, we considered the following 6 models to estimate $\lambda$ and $f$ :

(1) $\phi_{(.)} p_{(.)} \lambda_{(.)}$

(2) $\phi_{(t)} p_{(.)} \lambda_{(T)}$

(3) $\phi_{(t)} p_{(.)} \lambda_{(t)}$

(4) $\phi_{(t)} p_{(t)} \lambda_{(t)}$

(5) $\phi_{(t)} p_{(.)} \lambda_{\text {prairie dog }}$

(6) $f_{\text {prairie dog }}$ with $\phi$ and $p$ structure from best $\lambda$ model

\section{Goodness-of-fit}

We used the total chi-square value from Tests 2 and 3 in program RELEASE (Burnham et al. 1987) as a test of goodness-of-fit of our mountain plover data to the Pradel lambda model. We checked for overdispersion in these data using an estimate of $c$ from RELEASE, that we obtained by dividing the total chi-square by its degrees of freedom.

We computed the ratio of differences in log likelihood values as an approximate measure of the proportion of deviance explained by the best model (Skalski et al. 1993). We calculated this quantity as:

$$
\begin{gathered}
\text { Proportion of deviance }=[\log L \text { (best) } \\
-\log L(.)] /[\log L \text { (global) }-\log L(.)]
\end{gathered}
$$

using log likelihoods from the best model, the global $\left(\phi_{(t)} p_{(t)} \lambda_{(t)}\right)$ model, and the simplest $\left(\phi_{(.)}\right.$ $\left.p_{(.)} \lambda_{(.)}\right)$model. Here, the simplest model had 3 parameters $(\phi, p$, and $\lambda)$, and the global model had full year-effects on $\phi, p$, and $\lambda$ (15 parameters).

\section{Model Selection}

We selected an appropriate model using the methodology of Burnham and Anderson (2002). 
First, we ranked the set of $R$ candidate models using Akaike's Information Criterion (AIC; Akaike 1973). The use of AIC provides a means of objectively ranking a set of models and then selecting a best approximating model or models for inference (Burnham and Anderson 2002). To correct for possible small sample bias, we used $\mathrm{AIC}_{c}$ to rank models. We defined $\mathrm{AIC}_{c}$ as:

$$
\mathrm{AIC}_{c}=-2 \log L+2 K[n /(n-K-1)]
$$

where $\log L$ was the natural logarithm of the likelihood function evaluated at the maximum likelihood estimates, $K$ was the number of estimable parameters, and $n$ was the sample size. Here, the sample size was the total number of releases (new releases plus resightings). The second term in the above equation was a correction for small sample size.

Once we computed $\mathrm{AIC}_{c}$ values for each model, we ranked the $R$ models relative to the model with the minimum $\mathrm{AIC}_{c}$ value. We made comparisons between models using $\triangle \mathrm{AIC}_{c}$ values, where for each model $i$ :

$$
\Delta \mathrm{AIC}_{c_{i}}=\mathrm{AIC}_{c_{i}}-\mathrm{AIC}_{c_{\text {min }}}
$$

The $\Delta \mathrm{AIC}_{c}$ values compared the relative distances between the best approximating model $\left(\mathrm{AIC}_{c_{\text {min }}}\right)$ and each competing model $\left(\mathrm{AIC}_{c_{i}}\right)$. Generally, models with $\Delta \mathrm{AIC}_{c}$ values $\leq 2$ have strong support whereas those with $\triangle \mathrm{AIC}_{c}$ values $>10$ have little support (Burnham and Anderson 2002). We also computed normalized Akaike weights $\left(w_{i}\right)$ for each of the $R$ models as:

$$
w_{i}=\frac{e^{-\left(\frac{\Delta \mathrm{AIC}_{c_{i}}}{2}\right)}}{\sum_{r=1}^{R} e^{-\left(\frac{\Delta \mathrm{AIC}_{c_{r}}}{2}\right)} .}
$$

These normalized weights provided another means of directly evaluating the strength of evidence for each model and were useful for computing parameter estimates that reflected model selection uncertainty (Burnham and Anderson 2002). Parameter estimates in MARK were maximum likelihood estimates with $95 \%$ confidence intervals based on a logit or log transformation. Instead of using parameter estimates from a single best model, we model averaged (Burnham and Anderson 2002) parameter estimates across all 5 candidate models. This procedure weighted the individual parameter estimates according to their
Akaike weights; parameter estimates from models with higher weights received stronger support than those from models with little or no weight.

Using the Akaike weight and estimate of lambda $(\lambda)$ from each of the $R$ models, we computed a model averaged estimate of $\lambda$ as:

$$
\overline{\hat{\lambda}}_{i}=\sum_{r=1}^{R} w_{i} \hat{\lambda}_{i}
$$

with sampling variance:

$$
\operatorname{vâr}\left(\overline{\hat{\lambda}}_{i}\right)=\left[\sum_{r=1}^{R} w_{i} \sqrt{\operatorname{var}\left(\hat{\lambda}_{i} \mid M_{i}\right)+\left(\hat{\lambda}_{i}-\overline{\hat{\lambda}}_{i}\right)^{2}}\right]^{2}
$$

where $M_{i}$ was the $i$ th model in the candidate set (Buckland et al. 1997). The 95\% confidence interval for model-averaged estimates of $\lambda$ was:

$$
\begin{aligned}
& 95 \% \mathrm{CI}_{L}=\hat{\lambda}_{i}-1.96\left[\mathrm{SE}\left(\hat{\lambda}_{i}\right)\right] \\
& 95 \% \mathrm{CI}_{U}=\overline{\hat{\lambda}}_{i}+1.96\left[\mathrm{SE}\left(\overline{\hat{\lambda}}_{i}\right)\right]
\end{aligned}
$$

where:

$$
\mathrm{SE}\left(\overline{\hat{\lambda}}_{i}\right)=\sqrt{\operatorname{vâr}\left(\overline{\hat{\lambda}}_{i}\right)} .
$$

\section{RESULTS}

The pooled results from Tests 2 and 3 in program RELEASE showed there was a good fit to the Pradel lambda model $\left(\chi_{10}^{2}, P=0.41\right)$. There was no evidence of extra binomial variation in these data $(\hat{c}=1.03)$. The proportion of deviance explained by the best model was $49 \%$ of variation. Model-averaged estimates of $\lambda$ showed that the population of mountain plovers in southern Phillips County, Montana, increased rapidly from 1995-1998 and then appeared to stabilize in 1999 (Fig. 3). During the period of increase from 1995 to 1998 , the estimates of $\lambda$ were $>1$, but $\lambda$ could not reliably be judged different from 1 in 1999 .

We found good evidence supporting an effect of the hectares of active prairie-dog colonies on $\lambda$, but the effect on the log scale was negative $\left(\hat{\beta}_{\text {prairie-dog }}\right.$ $=-0.11 ; 95 \%$ CI was $-0.17,-0.05)$. We also found good evidence for a negative linear time trend in $\lambda$ on the log scale in the third best model $\left(\hat{\beta}_{T}=\right.$ $-0.09 ; 95 \%$ CI was $-0.14,-0.04)$. This model had stronger support $\left(w_{i}=0.31\right)$ than models where $\lambda$ was time-specific or constant across time (Table 1).

Using the best lambda and survival model, we estimated recruitment instead of lambda (Table 1). This model received only slightly less support 
than the best $\lambda$ model $\left(\Delta \mathrm{AIC}_{c}=0.07, w_{i}=0.32\right)$. The effect of area occupied by prairie dogs was still strongly negative on the logit scale $\{\beta$ the $=-0.23 ; 95 \% \mathrm{CI}$ was $-0.36,-0.10\}$ in this model. Estimates of $f$ gradually declined from 0.72 in 1996 to 0.38 in 2000 (Table 2).

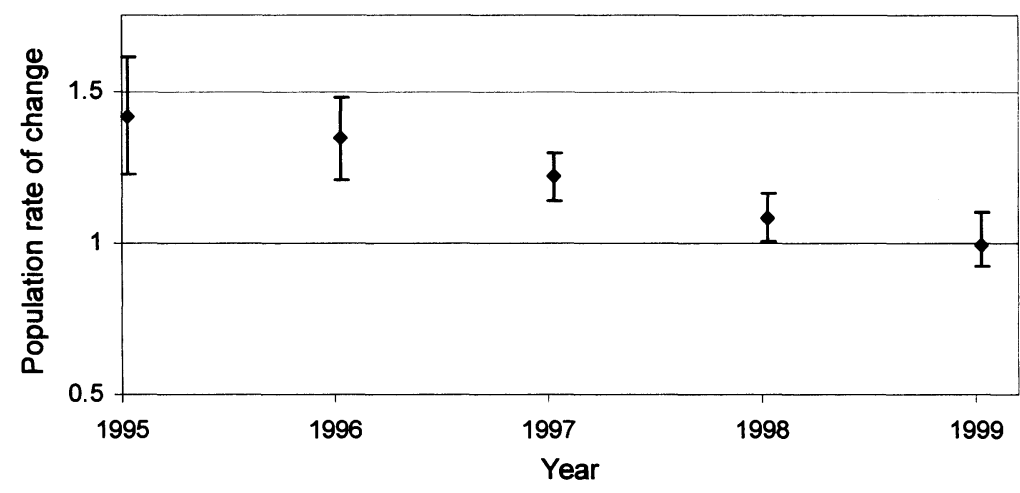

\section{DISCUSSION}

\section{Interpretation of $\lambda$}

The model selection results generally agreed with earlier findings on apparent survival and capture probabilities, lending support to estimates of $\lambda$ from the Pradel model. Earlier, we found that adult survival showed little annual variation and that captCynomys ludovicianusure probabilities were high with only slight annual variation (Dinsmore et al. 2003). Pradel models with the same constraints on apparent survival and capture probability received the best support of the models we considered. Due to limitations in the Pradel model that forced capture probabilities to be estimated as a single parameter, these estimates of $\lambda$ should still be interpreted with caution. Improper modeling of capture probabilities may have resulted in slightly biased estimates of annual population trends. Ultimately, a robust design Pradel model is needed to properly model capture probabilities and generate less biased estimates of $\lambda$ for this population.

Table 1. Summary of model selection results for the population trends of breeding adult mountain plovers in southern Phillips County, Montana, USA, 1995-2000. Models are ranked by ascending $\triangle A I C_{c} ; w_{i}$ is the model weight, and $K$ is the number of parameters. We modeled apparent survival $(\phi)$, capture probability $(p)$, recruitment rate $(f)$, and the finite rate of population change $(\lambda)$ to include no time effects (.), a linear time trend $(T)$, full time effects $(t)$, or an effect of area occupied by prairie dogs (prairie dog) ${ }^{a}$

\begin{tabular}{lrrrrr}
\hline Model & Deviance & \multicolumn{1}{c}{$K$} & \multicolumn{1}{c}{$\mathrm{AIC}_{c}$} & \multicolumn{1}{c}{$\Delta \mathrm{AIC}$} & $w_{i}$ \\
\hline$f_{(t)} P_{(.)} \lambda_{\text {prairie-dog }}$ & $2,565.05$ & 8 & $2,581.24$ & 0.00 & 0.33 \\
$f_{(t)} P_{(.)} f_{\text {prairie-dog }}$ & $2,565.12$ & 8 & $2,581.31$ & 0.07 & 0.32 \\
$f_{(t)} P_{(.)} \lambda_{(())}$ & $2,565.21$ & 8 & $2,581.40$ & 0.17 & 0.31 \\
$f_{(t)} P_{(.)} \lambda_{(t)}$ & $2,564.71$ & 11 & $2,587.06$ & 5.83 & 0.02 \\
$f_{(t)} p_{(.)} \lambda_{(.)}$ & $2,581.34$ & 3 & $2,587.37$ & 6.13 & 0.02 \\
$f_{(t)} P_{(t)} \lambda_{(t)}$ & $2,564.07$ & 15 & $2,594.71$ & 13.47 & 0.00 \\
\hline
\end{tabular}

a We computed deviance as $-2\left[\log _{e}(L(\hat{\theta}))-2 \log _{\theta}\left(L_{s}(\hat{\theta})\right)\right]$ where represented a maximum likelihood estimate whose loglikelihood was evaluated for the model in question $[L(\hat{\theta})]$ and for the saturated model $\left[L_{s}(\hat{\theta})\right]$.
Estimates of $\lambda$ are susceptible to bias if the size of the study area changed during the study (Franklin et al. 1999). In our study, population trends represented real trends and were not a reflection of changes in the size of area studied. The boundaries of the study area were fixed for the duration of the 6-year study. Within the study area, we attempted to survey all known prairie-dog colonies for plovers. We occasionally missed some small colonies, but plovers seldom occupied these colonies (Olson-Edge and Edge 1987). Thus, study area coverage was nearly complete each year, and population trends reflected real changes in the numbers of mountain plovers within this area.

\section{Prognosis}

At present, the mountain plover population in southern Phillips County appears to be stable at approximately 175 individuals (Dinsmore et al. 2003). The viability of such a small population is unknown, although they successfully rebounded from estimated population levels below 100 individuals in the mid-1990s. Our results suggest that the population increased rapidly from 1995 to 1998, possibly from in situ reproduction, but more likely from a combination of reproduction and

Table 2. Model averaged (except for $f$ ) estimates $( \pm S E)$ of apparent survival $(\phi)$, recruitment $(f)$, and finite rate of population change $(\lambda)$ from the Pradel model for adult mountain plovers in southern Phillips County, Montana, USA, 1995-2000.

\begin{tabular}{ccccccc}
\hline Year & $\phi$ & SE $(\phi)$ & $f$ & SE $(f)$ & $\lambda$ & SE $(\lambda)$ \\
\hline 1995 & 0.68 & 0.06 & NA & NA & 1.42 & 0.10 \\
1996 & 0.69 & 0.05 & 0.72 & 0.08 & 1.34 & 0.07 \\
1997 & 0.63 & 0.04 & 0.69 & 0.07 & 1.22 & 0.04 \\
1998 & 0.62 & 0.04 & 0.57 & 0.04 & 1.08 & 0.04 \\
1999 & 0.63 & 0.05 & 0.44 & 0.04 & 0.99 & 0.06 \\
2000 & NA & NA & 0.38 & 0.04 & NA & NA \\
\hline
\end{tabular}


immigration from surrounding areas such as Fort Belknap Indian Reservation (Dinsmore et al. 2003). During 2000-2001, there were signs of another sylvatic plague outbreak in prairie dog populations in southern Phillips County. Because mountain plovers in this region are closely tied to black-tailed prairie dog numbers, any future reductions in area occupied by prairie dogs will likely negatively impact plovers. Monitoring plovers through a sylvatic plague outbreak would be useful for noting the timing and magnitude of declines and recovery and correlating these changes to the area occupied by prairie dogs.

We cannot address whether the estimate of 175 breeding adults is sufficient to sustain this population for an extended period. Recruitment was high in 1995, but it gradually declined with an increase in the area occupied by prairie dogs, a pattern similar to that exhibited by estimates of annual survival (Table 2). The high estimates of recruitment relative to estimates of survival suggest that recruitment was an important component of population growth in this population. This in turn suggests that immigration may have played an important role in this rapid recovery.

We found a strong negative relationship between the area occupied by prairie dogs and both $\lambda$ and $f$. Prairie-dog colonies were a preferred habitat for mountain plovers in this region (Olson 1984), so we initially expected to find a positive relationship between area occupied by prairie dogs and both population growth and recruitment. It is clear that this population is rebounding in concert with an increase in the area occupied by prairie dogs. If the rate of change in the area occupied by prairie dogs was slower than the rate of change in plover numbers, then such a negative relationship could result. The result was that plovers may not have been able to colonize new prairie dog colonies as fast as they were becoming available. Or, perhaps the area occupied by prairie dogs was not the best measure of plover habitat; colony-specific features, the spatial arrangement of colonies, or the site fidelity of plovers may all be more important, and these factors are not related to the total area occupied by prairie dogs.

This information should provide a more solid foundation on which to build conservation measures for mountain plovers. Mountain plovers were recently identified as highly imperiled in a review of North American shorebirds, 1 of 5 shorebird species receiving this designation (Brown et al. 2001). A petition to federally list the species as Threatened was withdrawn in 2003 (U.S. Depart- ment of the Interior 2003). With this heightened interest in their conservation, mountain plovers will undoubtedly be the subject of various measures designed to reverse their recent declines.

\section{MANAGEMENT IMPLICATIONS}

The patchy distribution, low breeding densities, and widespread declines of mountain plovers make them a solid candidate for conservation measures. Plovers are a highly specialized, endemic bird of the western Great Plains and have adapted to a herbivore-driven, arid ecosystem. Threats to their continued existence are many and include habitat loss on the breeding and wintering grounds, regional changes in grazing practices, declines of a primary herbivore (black-tailed prairie dogs), and perhaps threats from agriculture (Knopf and Rupert 1996). One of the greatest threats to mountain plovers in Montana, and possibly elsewhere within their breeding range, is the continued loss of prairie-dog colonies. Montana has begun work on a statewide prairie dog management plan (Knowles 1999) and there is hope that this will be used to increase prairie dog numbers in the state. The results of this study illustrate that mountain plovers are at least partly dependent on black-tailed prairie dogs within part of their range (Montana), and that the conservation of prairie dogs is thus imperative for plovers in that region.

\section{ACKNOWLEDGMENTS}

We are grateful to Fort Carson Military Reservation (U.S. Department of Defense), the U.S. Fish and Wildlife Service (Colorado Fish and Wildlife Management Assistance Office), the Biological Resources Division of the U.S. Geological Survey, the U.S. Bureau of Land Management (Malta Field Office, Montana, USA), the Denver Zoological Foundation, and the Fort Belknap Tribal Community for financial support. The staff at Charles M. Russell National Wildlife Refuge supplied additional logistical support. J. J. Grensten and B. D. Rosenlund assisted with multiple aspects of the study. Field assistance was provided by A. Brees, D. C. Ely, T. Hanks, J. G. Jorgensen, C. McQueary, and T. Vosburgh. We thank B. Matovitch, D. Robinson, and J. Robinson for allowing us access to their lands. This is contribution number WF193 of the Forest and Wildlife Research Center, Mississippi State University.

\section{LITERATURE CITED}

AKAIKE, H. 1973. Information theory and an extension of the maximum likelihood principle. Pages 267-281 
in B. N. Petran and F. Csaki, editors. International symposium on information theory. Second edition. Budapest, Hungary.

BARNES, A. M. 1993. A review of plague and its relevance to prairie dog populations and the black-footed ferret. Pages 28-37 in J. L.Oldemeyer, D. E. Biggins, B. J. Miller, and R. Crete, editors. Management of prairie dog complexes for the reintroduction of the blackfooted ferret. U.S. Fish and Wildlife Service Biological Report 13.

Brown, S., C. Hickey, B. HaRrington, AND R. Gill. 2001. The U.S. shorebird conservation plan. Second edition. Manomet Center for Conservation Sciences, Manomet, Massachusetts, USA.

Bucki.and, S. T., K. P. Burnham, AND N. H. Augustin, 1997. Model selection: an integral part of inference. Biometrics 53:603-618.

BurNhAM, K. P., D. R. ANDERSON, G. C. WhITE, C. BroWNIE, AND K. H. POLLOCK. 1987. Design and analysis methods for fish survival experiments based on release-recapture. American Fisheries Society Monograph 5. AND - 2002. Model selection and multimodel inference: a practical information-theoretic approach. Springer-Verlag, New York, USA.

CASWELL, H. 2001. Matrix population models. Second edition. Sinauer, Sunderland, Massachusetts, USA.

DinSmore, S. J., G. C. White, AND F. L. KNOPF. 2003. Annual survival and population estimates of mountain plovers in southern Phillips County, Montana. Ecological Applications 13:1013-1026.

FRANKLIN, A. B. 2001. Exploring ecological relationships in survival and estimating rates of population change using program MARK. Pages 290-296 in R. Field, R. J. Warren, H. Okarma, and P. R. Sievert, editors. Wildlife, land, and people: priorities for the 21 st century. Proceedings of the second international wildlife management congress. The Wildlife Society, Bethesda, Maryland, USA.

, D. R. Anderson, E. D. Forsman, K. P. Burnham, AND F. W. WAGNER. 1996. Methods for collecting and analyzing demographic data on the northern spotted owl. Studies in Avian Biology 17:12-20.

, K. P. BuRNhaM, G. C. WhITE, R. G. ANTHONY, E. D. Forsman, C. SChWARZ, J. D. Nichols, AND J. E. HiNes. 1999. Range-wide status and trends in northern spotted owl populations. U.S. Geological Survey, Biological Resources Division, Corvallis, Oregon, USA.

KNOPF, F. L. 1994. Avian assemblages on altered grasslands. Studies in Avian Biology 15:247-257.

, AND B. J. MILLER. 1994. Charadrius montanus-montane, grassland, or bare-ground plover? Auk 111:504-506. - AND J. R. RUPERT. 1996. Reproduction and movements of mountain plovers breeding in Colorado. Wilson Bulletin 108:28-35.

KNOWLES, C. J. 1999. A species conservation plan for the black- and white-tailed prairie dogs in Montana. Draft report to the Montana Department of Fish, Wildlife, and Parks, Helena, USA.

, AND P. R. KNOWLES. 1984. Additional records of mountain plovers using prairie dog towns in Montana. Prairie Naturalist 16:183-186.

, C. J. StONER, AND S. P. GIEB. 1982. Selective use of black-tailed prairie dog towns by mountain plovers. Condor 84:71-74.

Lebreton, J. D., K. P. BurnhaM, J. Clobert, AND D. R. ANDERSON. 1992. Modeling survival and testing biological hypotheses using marked animals: a unified approach with case histories. Ecological Monographs 62:67-118.

LESLIE, P. H. 1945. On the use of matrices in certain population mathematics. Biometrika 35:183-212.

Milligan, J. L., A. K. DAvis, AND S. M. AltiZER. 2003. Error associated with using colored leg bands to identify wild birds. Journal of Field Ornithology 74:111-118.

Olson, S. L. 1984. Density and distribution, nest site selection, and activity of the mountain plover on the Charles M. Russell National Wildlife Refuge. M.S. thesis, University of Montana, Missoula, USA.

—, AND D. EDGE. 1985. Nest site selection by mountain plovers in northcentral Montana. Journal of Range Management 38:280-282.

Olson-Edge, S. L., AND W. D. EDGE. 1987. Density and distribution of the mountain plover on the Charles M. Russell National Wildlife Refuge. Prairie Naturalist 19:233-238.

PRADEL, R. 1996. Utilization of capture-mark-recapture for the study of recruitment and population growth rate. Biometrics 52:703-709.

Skalski, J. R., A. Hoffman, ANd S. G. Smith. 1993. Testing the significance of individual- and cohort-level covariates in animal survival studies. Pages 9-28 in J.-D. Lebreton and P. M. North, editors. Marked individuals in the study of bird population. BirkhauserVerlag, Basel, Switzerland.

VosBuRGH, T. C., AND L. R. IRBY. 1998. Effects of recreational shooting on prairie dog colonies. Journal of Wildlife Management 62:363-372.

U.S. DEPARTMENT OF THE INTERIOR. 2002. Endangered and threatened wildlife and plants: threatened status and special regulation for the mountain plover. Federal Register 67(234):72396-72407.

2003. Endangered and threatened wildlife and plants: withdrawal of the proposed rule to list the mountain plover as threatened. Federal Register 68(174):53083-53101.

White, G. C., AND K. P. BuRnhaM. 1999. Program MARK: survival estimation from populations of marked animals. Bird Study 46:120-139.

Associate Editor: Kelly. 